\title{
Cultural Impediments to Socio-Economic Development in Nigeria: Lessons from the Chinese Economy
}

\author{
Adebayo Olufemi Fadeyi ${ }^{1} \&$ Waziri Babatunde Adisa ${ }^{2}$ \\ ${ }^{1}$ Department of Sociology, Lagos State University, Ojo, Lagos State, Nigeria \\ ${ }^{2}$ Department of Sociology, University of Lagos, Akoka, Nigeria \\ Correspondence: Adebayo Olufemi Fadeyi, Department of Sociology, Lagos State University, Ojo, Lagos State, \\ Nigeria. Tel: 234-806-233-1394. E-mail: fadeyi2@yahoo.com
}

Received: January 10, 2012 Accepted: June 12, 2012 Online Published: June 28, 2012

doi:10.5539/jsd.v5n7p127

URL: http://dx.doi.org/10.5539/jsd.v5n7p127

\begin{abstract}
This paper attempts to describe how human environment is an important determinant of socio-economic development. Over the past three decades, Nigeria has been confronted with deep-seated socio-economic crisis evident in high level of poverty, inflation, foreign debt overhang, closure of industries, epileptic power supply, budget deficit, absolute lack of good governance at the grass root, environmental degradation and high unemployment. In the early part of the $21^{\text {st }}$ century, there was high hope among Nigerians that the emergence of democracy and the increasing global capitalist markets feasible in the oil and telecommunication sectors will result in high level of accelerated development. Elsewhere in Asia, globalization and world capitalist market have changed the faces of fundamental problems of underdevelopment. Studies have even confirmed that the successes recorded by China in the global markets confirm that a country's economy does not grow in vacuum; it exists within the environment and thrives therein. The failure and crises experienced in Nigeria today have been linked with cultural factors such as corruption, leadership failure, lack of entrepreneurial skills, over dependence on western values and culture, insincerity and weak bureaucracies. Using quantitative data and content analysis, the paper concludes that Nigerian government at all levels must rise up to the challenges posed by the problems of underdevelopment in the $21^{\text {st }}$ century.
\end{abstract}

Keywords: cultural impediments, socio-economic development, good governance, global markets, poverty, underdevelopment

\section{Introduction}

Although Nigeria is rich in human and material resources, its economic and political developments have been fraught with crises since independence in 1960. Indices of the failure of the Nigerian state are today evident in the pervasive cases of hunger, inflation, budget deficits, debt overhang, street begging, prostitution, frauds, high crime rates in major cities, collapse of manufacturing industries, corruption in public service and stagnation in entrepreneurial development. While the Nigerian economy has been preoccupied with these crises, it has also become difficult for sustainable development to take place in the country (Onimode, 1993; Dibie, 1998; NISER, 2000; UNDP, 2006). Until recently, the international community was not poised at looking at the specific factors that have contributed to economic stagnation in Africa and proffer formidable solutions to addressing economic development, good governance and the rule of law.

With the collapse of the World Bank and International Monetary Funds Policy's projects on Structural Adjustment Programme (SAP) in Africa, many questions have been raised by scholars on the factors impeding economic development in leading African nations including Nigeria (Ake, 1996; Jega, 2003). They argued that economic liberization in other parts of the world have continued to yield anticipated results, increasing global trade and technological advancements such that by the end of the $21^{\text {st }}$ century some emergent economies have appeared on the global capitalist markets. It is no gainsaying the fact that the likes of Indonesia, China, Japan and Malaysia are now making new waves in the global markets. While this thinking continues about global capitalist development, researches conducted by the United Nations and the World Bank et al. have shown that Nigeria's economic development is routinely constrained by some inherent cultural factors (NISER, 2000). It is in an attempt to identify, discuss and proffer possible suggestions to this problem that we have embarked on this heuristic exercise. This 
paper is divided into five sections including the introduction. Section two contains the theoretical framework while section three embarks on a brief analysis of the origin of the Nigerian economic crisis. The penultimate section identifies the cultural impediments to Nigeria's economic prosperity.

Economic development is defined as a process whereby a country is said to be undergoing or experiencing significant progress in its economic variables such as the Gross Domestic Product, Gross National Product, Per capita income, International Trade, Balance of Payments. Economic development implies the process whereby a country's economic potentials are harnessed towards sustainable human development. It is a robust combination of human and material resources to achieve economic, social, scientific and technological changes for the immediate and future needs of the citizenry. But it is important to note that the level at which a country achieves economic development varies from time to time; this is because it depends on the nature of the state, and the political will displaced by the leaders of the state to create enabling environment for economic productivity. The overall effects of any kind of economic development must be to bring about appreciable social and economic transformations which should also reflect in the lives of the citizenry (Ake, 1996; USAID, 2000).

Culture, within the context of this paper, is defined as the totality of ways of life of the people. Nigerian culture refers to the totality of the customs, values, knowledge, politics and economic practices of Nigerians which are either influenced domestically or internationally. It is important to note that Nigerian culture cannot exist in isolation of its environment; we therefore hold that the Nigerian culture is culture that predates the colonial era. With the amalgamation of the Lagos Colony with the Northern and Southern Protectorates, the previously dispararte ethnic groups have come to see themselves as Nigerians. Thus, the cultural practices that are associated with the Nigerian state and Nigerian society are what we refer to as the Nigerian culture. While some of these cultural practices have helped to sustain Nigerian image internationally, it is disheartening to learn that Nigerian economic development have been hampered by a number of cultural factors, mostly notable in the post-independence era (Osuntokun \& Olukoju, 1997).

\section{Material Studies and Area Description}

The political economy theory is one, out of many theories that Social Scientists often use to explaining the processes, forms and stages of economic growth and economic development in modern state. Central to the debates of adherents of the political economy theory on the processes of economic development, is the question of what pattern should economic progress in a country take? Another fundamental question is the question of what is supposed to be the role of the state and that of the capitalists in economic development. Reacting to the postulations of historians that social changes are unpredictable, the classical economists starting from Ricardo and Smith were of the opinion that change is not permanent. This was because the kind of changes that accompanied the Industrial Revolution has become a watershed in world history up till today. Thus, the classical economists insist that stages of economic growth of any country are predictable as opposed to the position offered by classical historians. The only guiding philosophy of any economic change is capitalism. A country can be said be growing when the state is able to harness the available factors of production through public and private competitiveness that can be bring about feasible development. The level and degree of economic prosperity depend largely on whether a country is placed in a vantage position to use the means of production including labour and capital to develop its people and its territory. No wonder, $\mathrm{Ne}$-Liberalism insists that countries in the developing countries must join in the global trade so as to get integrated into the system (Smith, 2003; UN, 2003). But it is obvious that not everybody benefits equally in the so much cherished capitalism by the classical economists. Because capital is the basis of negotiation in a capitalist society, majority of the people who are not usually able to control capital become agents of capital. Thus, their lifetime ambitions are subjected to whims and caprices of capital. This indeed is the basis of class antagonism between the bourgeoisie and proletariats, in the midst of this struggle is the tendency for the state to take over the ownership of the means of production while it lives a few sectors for the employers of labour to control. This is what Karl Marx refers to as alienation of labour and class struggle, and the faults of a capitalist society.

Analyzing substantial aspects of Karl Marx works on capitalism, a group of scholars emerged with a critique of capitalist mode of production. These scholars are often referred to as Marxist theorists. According to them, capitalism is an aberration to human race because it is a process whereby popular needs are subverted for private needs. Marxists believed that, because the quest for private ownership of capital and property is at the heart of capitalism, both the capitalists and the state which they control 
usually subdue the rest of the society to their whims and caprices thereby entrenching suffering and frustration. Capitalism, to the Marxists breeds unequal power exchange that allows for the continuous domination of capital by the bourgeoisie (Onimode, 2003).

Writing about the political economy of Nigeria using Marx analysis of history; Olukoshi (1992), Nnnoli (1993), Dibie (2000) and Jega (2003) argued that the failure of the development enterprise in Nigeria can largely be attributed to lack of commitment of Nigerian leaders to socio-economic development. Identifying colonialism as an offshoot of mismanagement of state resources in Nigeria, the scholars argued that the emergent political class of the post-independence era should be blamed for the failure because, instead of harnessing human and material resources for sustainable development, they were rather preoccupied with the business of power acquisition as opposed to economic growth being pursued in other transition economies of the world. The result of this was that by the end of 1994, Nigeria's external debt had reached $\$ 30$ billion dollars, this incident happened at a time when the country's economic crisis that began in the early 1980s had reached its climax. One explanation that have been offered for this is that, wherever a country's environment lacks the essentials for development, it would be difficult for such country to witness or facilitate economic development. It is this problem that Claude Ake (1996) has referred to as the failure of development enterprise in Africa. The rest of this paper will therefore be anchored on the theoretical orientation that the management of the political economy of the Nigerian state is rather too awkward, when the kind of vigour needed to bring about economic growth and development was commitment to national interests.

\section{Methods}

Before the amalgamation of the Northern Protectorate, Southern Protectorate and the Lagos Colony in 1914, there was no country called Nigeria. Each region existed independently of the other with their distinct culture, history, law and customs. In 1861, the Lagos colony became parts of the British empire in Africa. The smooth penetration of Lagos paved way for the British overlords to seek further incursion through Native administration into the Southern region, of what is now called Nigeria. In the process of winning the territory for their metropolis, the British overlords were left with two options, one to impose their ways of life on the native population, two, to adapt the cultural practices of the native population to their culture in order to put the British as people that also appreciated the traditions of the African people. Considering the long time effects of this on the colonial occupation of Nigeria, the British used the second option and thereafter introduced the Indirect Rule System of government. It was this system that brought the so called hurriedly conceived 1914 amalgamation of the two protectorates and the Lagos state colony which gave birth to the Nigerian colonial state and the Nigerian culture. For most parts of the colonial era, agriculture was the mainstay of the Nigerian economy (Dibie, 2000), up till the 1960s. The agricultural economy provided both food and cash crops for Nigerians. A large portion of the Nigerian government revenues was coming from this sector. When oil was discovered in large quantity in Oloibiri in Rivers State in 1956, government started shifting its attention to oil relying on its exportation to metropolitan nations. Economic development at this period was largely determined by government who was controlling over $60 \%$ of the oil wealth. In the early 1970 s, prices of crude oil rose in the global market which led to increases in the revenues accruing to Nigerian government.

Unfortunately, in the early 1980s, global prices on crude oil depreciated affecting not only Nigeria but a gross majority of oil exporting countries in developing countries (Nnoli, 1993). As a result of this global economic crisis, Nigeria economy crashed and experienced a shock leading to the 1980s economic crisis that invited the introduction of SAP as an alternative economic policy. Ake (1996) felt that Nigeria's deepening crisis of underdevelopment at this period was as a result of bad leadership and public corruption. Writing on the subject matter, Ake aptly stated that "The huge revenues from the oil boom had been so badly mismanaged that after the peak of the boom in 1980, Nigeria went into continually increasing deficits. The external debt, which had been no more than $\$ 4,284$ million between 1960 and 1980 , rose to $\$ 12,181$ million in 1983 . By 1986 when the foreign exchange receipts had fallen to $\$ 6.8$ billion from $\$ 26$ billion in 1980, the external debt stood at an estimated $\$ 19.5$ billion. By 1985 there were grave doubts about Nigeria's credits worthiness, and it was becoming more difficult for Nigerian importers to open letters of credit. Imports dropped dramatically, from $\$ 15$ Billion in 1980 to $\$ 5.5$ million in 1986. There were shortages of essential goods, manufacturing inputs and spare parts. In June 1986, the government reluctantly embarked on a structural Adjustment Program” (Ake, 1996).

Some advocates of Neo-Liberalism have suggested that the governments should identify the major socio-economic and cultural constraints to economic prosperity in the Third World (Smith, 2003). This 
is because despite the effects of globalization on the economies of newer nations in Africa and Asia, Nigeria's economic development variables are continually displaying negative signs.

\section{Techniques}

Below is Table 1 showing the human development index and rank of some selected countries across the world.

Table 1. Human development index of selected countries

\begin{tabular}{|c|c|c|c|c|c|c|c|c|}
\hline & $\begin{array}{c}\text { HIGH MEDIUM } \\
\text { COUNTRIES }\end{array}$ & 1975 & 1950 & 1985 & 1990 & 1995 & 2000 & 2003 \\
\hline 1 & Norway & 0.869 & 0.888 & 0.898 & 0.912 & 0.936 & 0.956 & 0.963 \\
\hline 2 & Iceland & 0.863 & 0.886 & 0.896 & 0.915 & 0.919 & 0.943 & 0.956 \\
\hline 4 & Canada & 0.869 & 0.886 & 0.909 & 0.929 & 0.934 & ------ & 0.949 \\
\hline 6 & Sweden & 0.864 & 0.874 & 0.886 & 0.897 & 0.929 & 0.959 & 0.949 \\
\hline 10 & United States & 0.867 & 0.887 & 0.901 & 0.916 & 0.929 & 0.938 & 0.944 \\
\hline 11 & Japan & 0.857 & 0.882 & 0.895 & 0.911 & 0.925 & 0.936 & 0.943 \\
\hline 15 & United Kingdom & 0.845 & 0.854 & 0.863 & 0.883 & 0.921 & 0.948 & 0.939 \\
\hline 16 & France & 0.853 & 0.869 & 0.881 & 0.903 & 0.921 & 0.932 & 0.938 \\
\hline 20 & Germany & ----- & 0.861 & 0.869 & 0.888 & 0.913 & 0.927 & 0.930 \\
\hline \multirow[t]{2}{*}{41} & United Arab Emirates & 0.734 & 0.769 & 0.787 & 0.812 & 0.814 & ------ & 0.849 \\
\hline & $\begin{array}{l}\text { MEDIUM HUMAN } \\
\text { DEVELOPMENT }\end{array}$ & & & & & & & \\
\hline 61 & Malaysia & 0.615 & 0.659 & 0695 & 0.721 & 0.760 & 0.790 & 0.796 \\
\hline 84 & Philippines & 0.654 & 0.687 & 0.693 & 0.720 & 0.736 & ------ & 0.758 \\
\hline \multirow[t]{2}{*}{85} & China & 0.525 & 0.558 & 0.594 & 0.627 & 0.683 & ----- & 0.755 \\
\hline & $\begin{array}{l}\text { LOW HUMAN } \\
\text { DEVELOPMENT }\end{array}$ & & & & & & & \\
\hline 146 & Madagascar & 0.400 & 0.437 & 0.436 & 0.446 & 0.458 & ----- & 0.499 \\
\hline 148 & Cameroon & 0.416 & 0.463 & 0.505 & 0.514 & 0.494 & 0.500 & 0.497 \\
\hline 155 & Gambia & 0.284 & ------ & ------ & ------ & 0.424 & 0.457 & 0.470 \\
\hline 158 & Nigeria & 0.318 & 0.376 & 0.386 & 0.406 & 0.418 & ------ & 0.453 \\
\hline
\end{tabular}

Source: Compiled by the authors Fadeyi and Adisa (2008) from the Human Development Report, 2005.

From the above table, it is apparent that Nigeria is still far behind. Gambia, Cameroon, Madagascar while it is indeed very far from the medium developed countries like China and Philippines. Thus, some of the cultural factors that have been documented by studies which accounted for these differences in human conditions are discussed in the next section.

\section{Results}

Nigeria development challenges are well-known and documented. It is remarkable to note the consistency at which the major economic development issues often feature at different national and international fora. USAID (2002) stated that such reports can be found in Obasanjo Economic Blueprint of 1999, the Poverty Reduction Initiative of 2000. In year 2000, the Nigerian Institute of Social and Economic Research (NISER) published a well researched paper on the problems of economic development in Nigeria. The institute titled the book NISER Review of Nigerian Development, 2000. The results to be addressed are the cultural impediments to socio-economic development in Nigeria. Nigeria's development challenges are: 


\subsection{Statism and Rent Seeking}

This is identified as one of the most serious obstacles to Nigeria's match to economic development and sustainable human conditions. Statism implies the domination of economic policies of a particular country by the state. Statism is a philosophy which considers the government as the most appropriate manager of the economy, and gives individual governmental authorities substantial power over fundamental economic activities such as entrepreneurship and innovation, employment and Finance (NISER, 2000). The danger of statism in a developing country is monumental. Statism gives room for rent-seeking, the illegal accumulation of state wealth at the expense of the poor. Instead of allowing for smooth economic competitions, the state appears to be at every where protecting the selfish interest of the ruling elites (Olukoshi, 1992). Since Nigeria's independence, statism has been a major guiding principle of the government in driving the forces of economic development. It is therefore not surprising that in most statist countries, rent-seeking behaviour is a common occurrence. This partly explains the reason why Nigeria is a corrupt and rent-seeking society.

Corruption: Growing at independence as a fatal problem, corruption in Nigeria has reached an alarming stage. Though, corruption is a worldwide phenomenon, it has been observed as being a pervasive problem commonly found among the civil bureaucrats who have been in charge of Nigeria's development agenda. It is so pathetic to note that despite the effort of the Federal Government at combating the menace, the incidence of political corruption has defied major diagnosis. Thus, at the state level, it has become a major avenue for mismanagement of public funds and pursuit of economic interests which portend many dangers for sustainable democratic governance in the country. Corruption has so pervaded the entire Nigerian society such that it is difficult to know people who are still morally upright. The most devastating effects of corruption on development, is the supports it is giving to rent-seeking thereby hampering capital development projects. Large scale government industrial projects had been ruined by corruption in the past and a lot more are still being constrained by the pandemic (World Bank, 1997; Onimode, 2003; Saturday Vanguard, 2008). It is not surprising therefore that corruption is found in the oil, agricultural, communication, transportation, health and other sectors. Like other African countries, corruption in Nigeria is a major obstacle to sustainable development.

The "Commanding Heights" Philosophy: This involves state ownership of all major industries, state mobilization, direction of investment resources, and state planning. This policy implies that the state is found in every sector of the economy, private sector initiative is restricted while foreign investors see the economy as an unpredictable economy. Under successive military governments in Nigeria much power was concentrated in the Federal Government, this largely prevented free market competition and the emergence of a viable private sector that could accelerate economic development. Though, with the advent of genuine democratic governance, the Nigerian government is said to have considered the privatization of public enterprises as an alternative option to getting rid of economic recession, price fluctuation and technological backwardness (USAID, 2002). Another factor that has hindered Nigeria's economic development is military rule.

Military Rule: The emergence of the military on Nigerian political scene for twenty-nine years prevented foreign investment because military authoritarianism was not conducive for the rule of law which used to be grounds for smooth capitalist business. Thus, for almost three decades of military rule in Nigeria, the business environment suffered many setbacks, this was because the draconian government removed professionalism in economic planning and replaced it with mediocrity. Thus, the growth of military regimented lifestyles consequently facilitated the growth of statist culture, corruption and authoritarianism. As a vicious circle, authoritarian government built hostile environment and prevented foreign investment, while many domestic industries were closed down under the aegis of bad economic policy and inflation. More interestingly was the fact that under the regimes of Gen. Ibrahim Babangida and late Sanni Abacha, Nigeria's economic development reached its stalemate. While the former regime introduced SAP that compounded the economic conditions of Nigerians, the later perpetuated a lot of human rights abuse, which subsequently earned Nigeria sanctions from top capitalist nations like the United States and the United Kingdom. No wonder, pro-democracy activists have argued that a stable government is a potentiality for economic growth and human development (Oyediran, 1979). Dibie (2000:49-53) noted that under the military it was common for the federal government to claim monopoly of state resources and manager of the nation's development agenda. Though, the military has been disengaged from Nigerian politics since May 1999, political analysts opined that majority of ex-military leaders are still in the corridors of power. 


\subsection{Mono-cultural Economic Policy/the Dutch Disease}

Because of the misguided economic policies of successive Nigerian government, today Nigeria's national income largely depends on sales of crude oil to foreign multinationals. Today, the oil sector has dominated all other sectors of the economy leaving agriculture and manufacturing sectors worse off. In its research, USAID (2002) called this phenomenon the "Dutch Disease". It is an economic policy whereby only one commodity forms the major exportable commodity resulting ultimately in severe economic instability and vulnerability to the price behaviour of the commodity. USAID stated that one the common features of the Dutch Disease is the long term neglect of other sectors of a country's economy. It observed further that most countries trading in the developing countries depend largely on this policy to make their foreign incomes. Nigeria is a typical example of a country suffering from this disease. The reason for reaching this conclusion is based on the overbearing role of oil in the country's Gross Domestic Product. Today, oil forms over $95 \%$ of total export earnings, and these earnings alone comprise of GDP on an expenditure basis. About $75 \%$ of consolidated government revenue also come from oil (Olu \& Akande, 1999; NISER, 2000b).

\subsection{Misguided Trade Policy}

One of the factors in Nigeria's economic history that has hampered economic development was the policy of indigenization, import substitution and industrialization (ISI). By systematically shielding Nigeria away from international competition, the ISI policy ensured the progressive degradation of the country's competitiveness in almost all products other than oil. ISI prevented economic growth because government investment in indigenous industries cut short what would have been the role of global capitalist investors. No wonder, it had net negative effects on the balance of payments of the government. Thus, it was not as if Nigeria did not have the resources to develop its economy but that the Nigerian government embarked on a misguided economy policy. USAID (2002) has succinctly explained the reasons why the Nigerian economy has failed to develop. According to the multilateral organization:

"Several analyses have drawn our attention to the remarkable and instructive contrast between the economic performance of Nigeria and Indonesia over the past forty years. In 1965, both countries were very poor, raw material-based ex-colonial nations, with similar GDPs of $\$ 4-5$ billion, very large populations, both in the neighborhood of 100 million. Both were in the early stages of becoming major exporters, and over the period since then have earned roughly similar amounts from oil shipments. However, while non-oil exports in 1965 were similar in both countries, at about $\$ 500$ million, Indonesia's non-oil exports today are some $\$ 30$ billion, while Nigeria's still have not even reached \$1 billion. Meanwhile, Indonesia's total GDP has grown to \$225 billion-five times the size of Nigeria. Indonesia generates seven times more electric power than Nigeria. Nigeria's GDP per capita, the broadest measure of wealth, remains in the same range today as it was forty years ago, at around \$300. Indonesia's, which started at about the same level, has in contrast increased three-to fourfold over the period, to over $\$ 1100$ per capita. This divergence in performance is attributed to Indonesia's commitment at an early stage to private sector-oriented economic restructuring, better trade policy, much better management of the Dutch Disease, and more financially sustainable fiscal policy. Indonesia generally opted to be a participant in the global private competitive economy, in particular encouraging agriculture and light manufacturing such as apparel, which led to subsequent development of a range of Industrial products"(USAID, 2002).

\subsection{Entrepreneurial Achievement}

While the Nigerian state cannot but accept the blames being passed on it, it should be noted that many of its citizens lack the will and the achievement personality style to aid development. In contrast individuals with development motives tend to think towards innovation and development. They believe so much in originality and thus are motivated to contribute their quotas to human progress through advancement in science, technology and scholarship etc. (Dibie, 2000). Experiences in contemporary Nigerian society have shown that most Nigerians lack achievement motivation, and often prefer to engage in activities that are less stressful and less tasking. Much of their labour power is devoted to earning illegal profits. Although, government has recently embarked on activities that will increase public awareness on the importance of entrepreneurship for economic growth in a depressed economy, like that of Nigeria; there are still many people in the country, who are yet to understand the need for them to be self reliant through entrepreneurship. Self-reliance worldwide has been known to be correlated with increases in productivity, innovation and home-grown economic culture. Thus, entrepreneurial business is constructed as another tool for economic self-actualization of African and Asian countries. 


\subsection{Corrupt Financial System}

Corruption in Nigeria's financial system has been described as one of the problems of underdevelopment in the country. Corruption was said to be behind the collapse and closure of some previously ailing banks in the 1980s. By the end of 1990s, banks, which ought to play a prominent role in attracting international investment had lagged behind the global capitalist competitive markets. Worried by the financial recklessness and indiscipline in the banking industry, the Federal Government under President Olusegun Obasanjo had to merge the surviving banks into 25 Mega Banks. This was done in December, 2005 in order to refocus the banks for the challenges of the $21^{\text {st }}$ century global capitalist system. The guiding philosophy of the Federal Government in this regard was that the private sector needed a financial system that could withstand international standard, and that could bring about sustainable economic development (UNDP, 2007); and for that process to take place the corrupt and wrecked financial system of the past must be a thing of the past. While the Federal government was trying to solve this problem, there emerged another serious challenge which had its roots in the Nigerian multi-ethnic rivalries; this was the problem of violence. Since 1999, Nigerian state has not known absolute peace, it has been battling with different forms of violence, religious, political and ethnic and ethnic clashes. Most recent, is the persisetent Niger Delta crisis. Thus, this culture which is preventing private business in the country has been referred to as the culture of violence.

\subsection{The Culture of Violence as a Threat to Capitalist Development}

Whether in government enterprises, private sector businesses or international trades, many social scientists who have written extensively on the Neo-liberal economic agenda have argued that violence an impedes development. Violence creates hostile environment for economic growth and also creates fear in business people. A violent environment can never be conducive for peaceful trade negotiation. From the Nigeria Civil War of 1967-1970 to several religious clashes in the North, ethnic clashes in the South, insurgence of Niger Delta crisis and Political and Sectanan clashes in the North. Adams (2000) commented that violent political, ethnic and religious clashes are evidences of the failure of the Nigerian state.

\section{Discussion}

China's economic history is replete with several social and economic changes. Chinese historians have noted in many literature that China was one of the world's early economic giants but fluctuated as a result of Chinese political system which internally restricted socio-economic and technological changes. Evidence of this could be found in state domination of economic policies which reflected clearly in the role and position of China in the $18^{\text {th }}$ century's Industrial Revolution; the phenomenon which brought Europe into limelight of international trade (Wang, 2007) while China lost its past glory.

Breaking from the yoke of strict socialism, China embarked on serious economic reforms in 1978 but the fruit of Chinese reforms did not show until the 1990s. From 1978, China introduced its radical reforms, the Chinese government at all levels accelerated the processes of their economic structuring; changing from state planned economic system to a market-driven system whereby private individuals can compete favourably with their counterparts within and outside the country. The result of this; for Chinese businessmen is increased participation in the global business while the interest of their country is at the same time jealously protected (Hussain \& Stern, 2007). Remarking on the unprecedented reforms going on in China and the results accruing from them; Wang (2007) had this to say:

"China has moved toward the market and integrated more deeply with the world economy over the past 25 years. Having grown at more than 9 percent a year during that period, it is now the world's fourth-largest economy and third-largest exporter; and it is poised to continue growing at a rapid pace. Structural reform and economic growth have brought about an unprecedented rise in average living standards and a dramatic reduction in rural poverty. The changes have lifted 400 million Chinese out of poverty since 1980".

Increasingly, China has reduced the role of the state in economic restructuring paving way for full private sector participation. In order to achieve this; Chinese government decentralized more effectively than other members of the Organization for Economic Cooperation and Development (OECD) and other large middle-income countries, particularly on the spending side. For example, China has a different approach to the delivering of social services being rendered by the state to the citizens. While in most countries of OECD, social security, education, public health and justice are centralized; in China they are largely decentralized.

It is important to note that such decentralization in public expenditures has helped to reconcile discrepancies that might arise when the federal government dominates most of the policies on social welfare. Below is a diagram showing the patterns of decrease in Chinese government expenditure over the years between 1978 and 2004. 
Table 2. Government revenue and expenditure as a percentage of GDP, 1978-2004

\begin{tabular}{|c|c|c|c|}
\hline Year & $\begin{array}{c}\text { Revenue as Percentage of } \\
\text { GDP }\end{array}$ & $\begin{array}{c}\text { Expenditure as Percentage } \\
\text { of GDP }\end{array}$ & $\begin{array}{c}\text { Surplus as Percentage of } \\
\text { GDP }\end{array}$ \\
\hline 1978 & 31.2 & 30.9 & 0.3 \\
\hline 1979 & 28.4 & 31.8 & -3.4 \\
\hline 1980 & 25.7 & 27.2 & -1.5 \\
\hline 1981 & 24.2 & 23.4 & 0.8 \\
\hline 1982 & 22.9 & 23.2 & -0.3 \\
\hline 1983 & 23.0 & 23.7 & -0.7 \\
\hline 1984 & 22.9 & 23.7 & -0.8 \\
\hline 1985 & 22.4 & 22.4 & 0.0 \\
\hline 1986 & 20.8 & 21.6 & -0.8 \\
\hline 1987 & 18.4 & 18.9 & -0.5 \\
\hline 1988 & 15.8 & 16.7 & -0.9 \\
\hline 1989 & 15.8 & 16.7 & -0.9 \\
\hline 1990 & 15.8 & 16.6 & -0.8 \\
\hline 1991 & 14.6 & 15.7 & -1.1 \\
\hline 1992 & 13.1 & 14.1 & -1.0 \\
\hline 1993 & 12.6 & 13.4 & -0.8 \\
\hline 1994 & 11.2 & 12.4 & -1.2 \\
\hline 1995 & 10.7 & 11.7 & -1.0 \\
\hline 1996 & 10.9 & 11.7 & -0.8 \\
\hline 1997 & 11.6 & 12.4 & -0.8 \\
\hline 1998 & 12.6 & 13.8 & -1.2 \\
\hline 1999 & 13.9 & 16.0 & -2.1 \\
\hline 2000 & 15.0 & 17.8 & -2.8 \\
\hline 2001 & 16.8 & 19.4 & -2.6 \\
\hline 2002 & 18.0 & 21.0 & -3.0 \\
\hline 2003 & 18.5 & 21.0 & -2.5 \\
\hline 2004 & 19.3 & 20.8 & -1.5 \\
\hline
\end{tabular}

Source: World Bank, 2007:15.

Unlike Nigeria, Chinese government has since 1978 been making notable progress on its economic transformation. Notwithstanding the rise and fall in the revenue and expenditure; the Chinese state dominance of the capital market has been tracked down considerably since 1978 when the reform began. Hussain and Stern (2007) observed that in the three decades since the reforms began, in 1978, the relation between national income and budgetary revenue has undergone a dramatic change, first declining precipitously, then recovering dramatically as shown in Table 2. During the first 17 years, the budgetary revenue ratio dropped by almost 21 percent points, from 31.2 percent in 1978 to 10.7 percent in 1995. The next nine years saw the ratio increase to 19.3 percent in 2004. One of the significant features of the Chinese economy is the fact that Chinese public expenditure is not far from its revenue. The reverse is the case in Nigeria.

Since the beginning of the Structural Adjustment Programme (SAP) of 1986 in Nigeria; government expenditure has increased without considerable income until the early 1990s when oil price picked up. Because Nigeria's private sector had been weakened by the overbearing role of the state in economic restructuring; the percentage contribution of the sector to social services was and is still meager. For Nigeria to move away from these 
shackles of economic stagnation; it has to create an enabling environment for a market-driven economy; investment in research and development ( $R$ \& D), science and technology workers, information technology. Dahlman, Zeng and Wang (2007) observed that as a transition economy, China is seriously closing the gap between public and private expenditures on education at all levels. In advanced capitalist countries such as the United States, the private sector share in the financing of education is $54.9 \%$ compared to public sector share of $45.1 \%$, in India the public sector share is still relatively high at $77.8 \%$ compared to $22.2 \%$ for the private sector, in Indonesia the public sector has $43.8 \%$ less than that of the private sector of $56.2 \%$.

It has been observed that countries with higher participation of the private sector tend to outgrow their counterparts with governments larger share. The reason being that competition in the educational sector encourages, innovation, technological prowess and the development of science and research (see Dahlman, Zeng \& Wang, 2007).

Paradoxically, Nigeria falls among the countries of the world with high government interference in the financing of education. No wonder, the economy is stagnant and even resistant to changes. At this juncture, it is pertinent to reiterate that Nigeria should learn its lessons from transition economies especially China. Majorly, we are canvassing a market-driven economy and at the same time a democratic state. Investment in public education should not override private sector investment. Thus, Nigerian government should encourage stakeholders in the private sector by creating for them an enabling environment for sustained economic growth and development.

\section{Conclusion}

This paper has sustained a singular argument, that economic development does not exist in vacuum, that for Nigeria to experience viable economic growth and development, cultural problems such as corruption in government circle, mono-cultural economy, statism, urban violence and wastage of public funds must be address The paper demonstrated that China and Indonesia are leading examples for Nigeria. The two countries are emerging economies with vision and mission for sustainable economic growth. We therefore suggest here, that Nigeria too has the hope of restructuring its economy in the $21^{\text {st }}$ century. The task is before the Nigerian government to rise up to the challenges of eradicating cultural obstacles to economic development.

\section{Acknowledgement}

The authors are grateful to Emeka Stanley who provided typing assistance for this work.

\section{References}

Adams, W. (2000). Violence as a National Culture. The Guardian on Sunday.

Ake, C. (1996). Democracy and Development in Africa. Ibadan: Spectrum Books Ltd.

Dahlman, C., Zeng, D. Z., \& Wang, S. (2007). Financing Lifelong Leraning. In Lou, J. W., \& Wang, S. L. (Eds.), Public Finance in China: Reform and Growth for a Harmonious Society. Washington D.C.: The World Bank.

Dibie, R. (2000). Understanding Public Policy in Nigeria: A Twenty-First Century Approach. Lagos: Mbeyi and Associates.

Hussain, A., \& Stern, N. (2007). Public Finance, the Role of the State, and Economic Transformation 1978-2020. In Lou, J. W., \& Wang, S. L (Eds.), Public Finance in China: Reform and Growth for a Harmonious Society. Washington D.C.: The World Bank.

Jega, A. (2003). Identity Transformation and Identity Politics under Structural Adjustment in Nigeria. Kano: Nordiska Afrikainstitutet.

Lipset, S. M. (1959). Some Social Requisites of Democracy: Economic Development and Political Legitimacy. American Political Science Review, 53(5), 69-105. http://dx.doi.org/10.2307/1951731

Lou, J., \& Shulin, W. (2007). Public Finance in China: Reform and Growth for a Harmonious Society. Washington D.C.: The World Bank.

McClelland, D. C. (1961). The Achieving Society. A Free Press Paperback, The (London) Macmillan Company.

Nafziager, W. (1993). The Debt Crisis in Africa. Boltomre, U. K: John Hopkins University Press.

NISER. (2000a). NISER Review of Nigerian Development, 2000: The State in Nigerian Development. Ibadan, NISER.

NISER. (2000b). Public Sector Spending for Agriculture and Rural Development. NISER Technical Research Report, Ibadan, NISER. 
Olukoshi, A. (1992). The Politics of Structural Adjustment in Nigeria. London: James Carrey.

Oni, B., \& Akinbinu, B. (2005). Public-Private Partnership in Nigerian Development: A Multi- Disciplinary Approach. Ibadan: NISER et al.

Onimode, B. (1989). The IMF, the World Bank and the African Debt. The Economic Impact, 1 \& 2.

Osuntokun, A., \& Olukoju, A. (1997). Nigerian Peoples and Cultures. Lagos: Davidson.

Oyediran, O. (1979). Nigerian Government and Politics under Military Rule 1966-1979. New York: Martins Press.

Oyekanmi, F. A. D., \& Soyombo, O. (2006). Society and Governance: The Quest For Legitimacy in Nigeria. Lagos: Fredrick Ebert Foundation.

UNDP. (2005). Human Development Report. New York: UNDP.

USAID. (2002). Nigerian Economic Growth Activities: Transition Period Summary. Nigeria: IBM.

Wang, S. (2007). Overview. In Lou, J. W., \& Wang, S. L. (Eds.), Public Finance in China: Reform and Growth for a Harmonious Society. Washington D.C.: The World Bank. 